\title{
Scales, weights and weight-regulated artefacts in Middle and Late Bronze Age Britain
}

\author{
Lorenz Rahmstorf
}

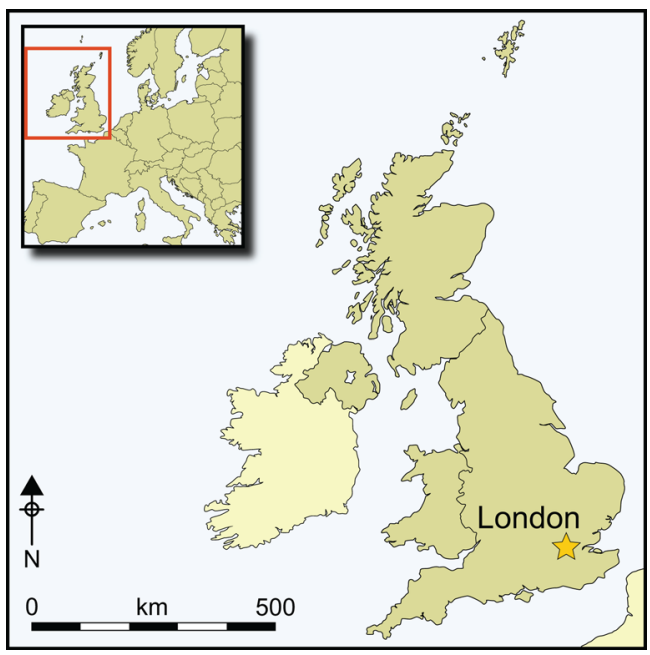

The identification of weights and weightregulated artefacts is of primary importance for confirming the existence of European Bronze Age value ratios and exchange systems. Until recently, however, no such Bronze Age artefacts had been identified in Britain. Here, statistical analysis identifies-for the first time-Middle and Late Bronze Age balance weights and weight-regulated gold objects from Britain, Ireland and Atlantic France. These finds allow for new interpretations concerning modes of exchange and their significance in Atlantic Europe, further underlining a Continental — and possibly Mediterranean-influence on Britain during the late second and early first millennia $B C$.

Keywords: Britain, Bronze Age, scales, weights, weight-regulated artefacts, exchange

\section{Introduction}

Trade is generally considered to be an inappropriate concept for explaining exchange in Bronze Age Europe (Harding 2013). Instead, exchange is usually understood as a social phenomenon reflecting the societal obligations between individuals (Brück 2006). One reason for the dearth of attention to profit-driven exchange, or trade, in Bronze Age Britain is probably the lack of archaeological finds that might indicate the existence of professional traders or the organisation of specialist exchange.

The use of standard weights and balance scales permits the precise measurement of the mass of material, particularly of metals. With such devices, it became possible to exchange specific amounts of various substances, such as metals, wool and grain, and allowed for the establishment of accurate 'material value ratios' between different substances. The definition

* Seminar für Ur- und Frühgeschichte, University of Göttingen, Nikolausberger Weg 15, D-37073 Göttingen,
Germany (Email: lorenz.rahmstorf@uni-goettingen.de)

(C) Antiquity Publications Ltd, 2019. This is an Open Access article, distributed under the terms of the Creative Commons Attribution licence (http://creativecommons.org/licenses/by/4.0/), which permits unrestricted re-use, distribution, and reproduction in any medium, provided the original work is properly cited.

ANTIQUITY 93371 (2019): 1197-1210

https://doi.org/10.15184/aqy.2018.257 
of such ratios brought about the meticulous calculation of potential profit, the creation of weight-based currencies and the possibility of long-term storage of weighed metal. All of these factors are essential for specialised/commercial exchange- which can simply be referred to as 'trade'. The fact that metal objects were produced using precise amounts of a particular material supports this definition of 'trade'. These 'weight-regulated artefacts' may have enabled exchange, as they provide specific, pre-weighed quantities of a material; such artefacts also may have been intentionally fragmented to provide fractional units. The transactions facilitated by the use of metrological objects, such as scales, weights and weight-regulated artefacts, are concluded when the exchange partners agree on value ratios: that is, the mass of one material is used as a currency in exchange for a certain mass of another material.

The identification of weights and weight-regulated artefacts is crucial for establishing the existence of value ratios, and hence trade, in past societies. Recently, an early example of the appropriation of weight-regulated (silver) objects as 'bullion-currencies' has been identified in the ancient Near East (Ialongo et al. 2018), and several scholars have identified early weighing equipment in specific parts of prehistoric Europe, including Italy, Central Europe and Portugal (Cardarelli et al. 1997; Pare 1999; Peake et al. 1999; Rahmstorf 2003; Vilaça 2003, 2011; Ialongo 2018; Ialongo \& Rahmstorf in press). Our general understanding of the use of weights in Bronze Age Europe, however, remains far from complete and, until now, nearly no weights or no weight-regulated artefacts have been identified from Bronze Age Britain. To fill a lacuna in the current distribution and knowledge of Bronze Age weighing equipment, this article presents Middle and Late Bronze Age as well as Early Iron Age balance weights and weight-regulated gold objects from Britain, Ireland and Atlantic France. In addition, it is argued that trade was already a common practice during these periods in North-western Europe - and potentially also in other parts of the continent, where contemporaneous weighing equipment has yet to be identified.

\section{Methods}

Early weighing equipment and weight-regulated artefacts are difficult to detect within large groups of assemblages of mixed artefact types. Only rarely are such objects inscribed or even marked, even in Egyptian and Mesopotamian contexts. To date, not a single clearly marked weight is known from Bronze Age Europe (outside of Greece). While potential data have often been ignored or misinterpreted, identifications of potential weights have been suggested (e.g. Rahmstorf 2014; Ialongo 2018). Thus, in order to identify metrological weights or weight-regulated artefacts within prehistoric contexts convincingly, the evidence must be evaluated on a case-by case basis. First, according to archaeological criteria, such artefacts should come from a related set of contexts (e.g. settlement contexts related to metal production and circulation). Potential weights or weight-regulated objects must constitute a distinct class of artefacts of variable sizes, must at least sometimes appear in groups and must not feature consistent patterns of use-wear on them. While some weights could display use-wear from everyday activity, they should not exhibit reoccurring patterns of wear on specific surfaces suggestive of their employment as simple tools, such as pounders or grinders. Archaeological evidence of balance scales of contemporaneous date may help to provide contextual support for the identification of weights. Second, the objects should undergo statistical

(C) Antiquity Publications Ltd, 2019 
analyses, by which they are tested using non a priori assumptions about the possible units of measurement.

Cosine quantogram analysis is an efficient and established method for detecting the relationship between the mass of an ancient balance weight or weight-regulated artefact and the measurement or quantal system of which it was a part (Pakkanen 2011; Ialongo et al. 2018). The term 'quantum' describes the mass: the common denominator of the largest possible number of measurements in a sample. The basic proposition is that a measurement $X$ (e.g. a gold object) is an integer multiple of unit $q$ (quantum), plus an error component $\varepsilon$. The error component is of particular importance, as it expresses the dispersion from an ideal distribution of the quantum (the potential unit). The so-called 'Kendall-formula' calculates the score of the error component $\epsilon$ in a number of measurements $(N)$ :

$$
\phi(q)=\sqrt{2 / N} \sum_{i=1}^{n} \cos \left(\frac{2 \pi \varepsilon_{i}}{q}\right)
$$

The formula tests the score of each quantum and results in a 'quantogram', with positive and negative peaks when plotted in a graph. A high positive peak appears where a quantum gives a high positive value for $\phi(q)$. These peaks may be interpreted as the weight unit, or fractions or multiples of it.

\section{Scales and weights from Middle and Late Bronze Age and Early Iron Age Britain}

In 2000, a Late Bronze Age (c. 1200 BC) balance beam of bone (Figure 1.1), discovered at Potterne in Wiltshire, was published (Lawson 2000: 257; Seager Smith 2000: 240, fig. 97). This has been followed more recently by further finds of weighing equipment, including a fragment of the centre of a balance beam, featuring a copper-alloy suspension loop, found at Cliffs End Farm on the Isle of Thanet, Kent (Grimm \& Schuster 2014: pl. 5.9, 1). This artefact dates from the Late Bronze to Late Iron Ages (Figure 1.2). The balance beam is not the only metrological tool from Cliffs End Farm (Needham et al. 2013: fig. 6.1), which has also yielded a conical lead weight featuring a perforation for the insertion of a metal-wire loop. This object was recovered from a burial pit (Mepham \& Schuster 2014: fig. 5.9, 11). According to the excavators, the pit's fill was not disturbed by later activity, and can therefore be dated securely to the tenth to ninth centuries BC (Figure 2.1a-b).

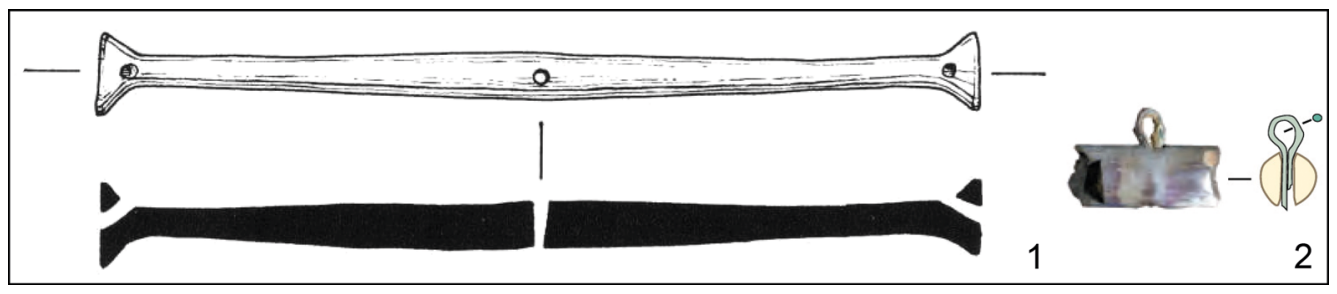

Figure 1. Balance beams of bone from late prehistoric Britain: 1) Potterne; 2) Cliffs End Farm 1 (images taken from Lawson 2000: 236; Grimm \& Schuster 2014: 188; courtesy of Wessex Archaeology; scale 1:1).

(C) Antiquity Publications Ltd, 2019 


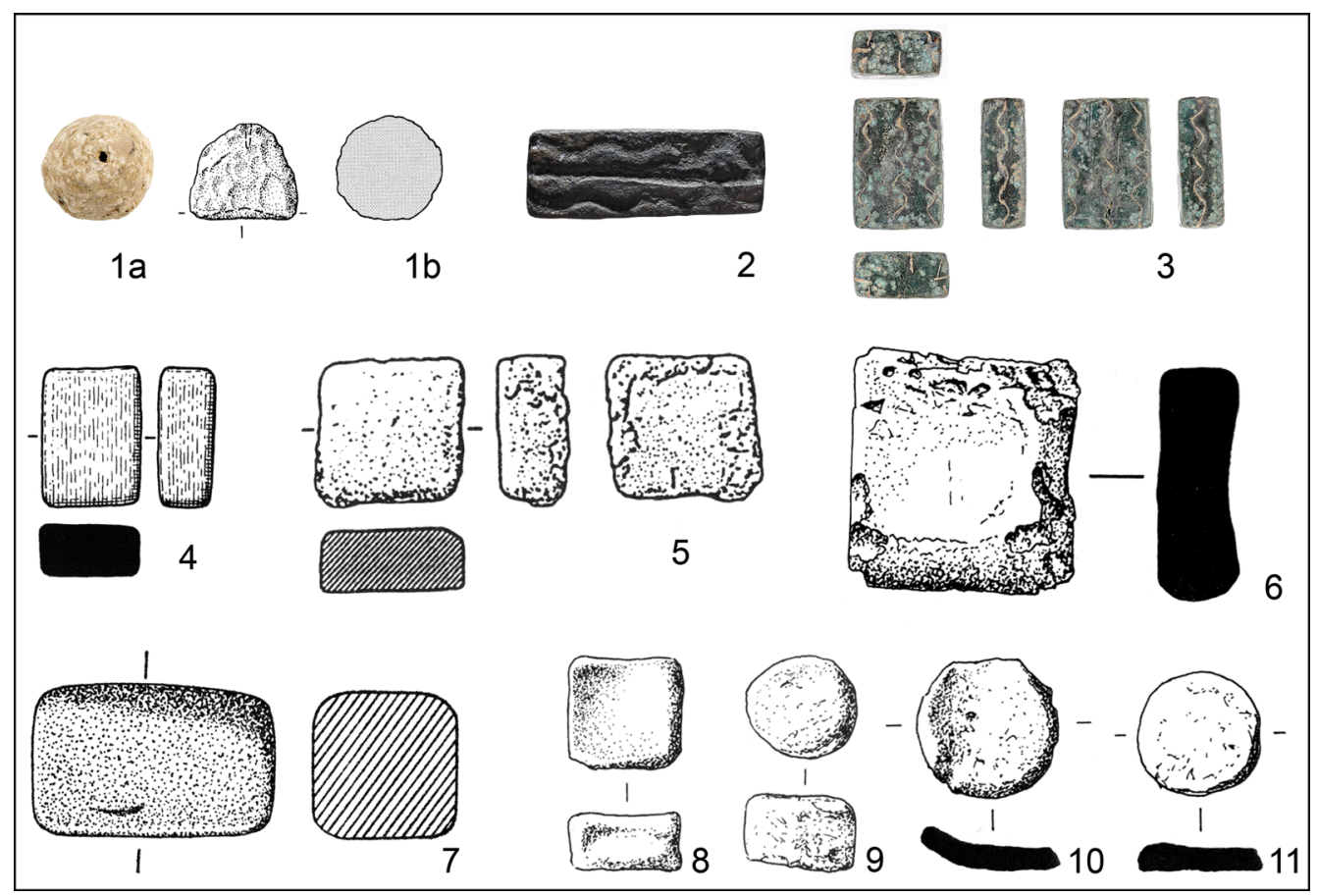

Figure 2. Potential weights from Middle and Late Bronze Age and Early Iron Age Britain (1-2 \& 4: bronze; 5-6, 811: lead; 7: stone): 1) Cliffs End Farm, Thanet, Kent; 2) Salcombe; 3) Denton with Wootton; 4) Salcombe; 5) Runnymede Bridge; 6) West Caister; 7) Heathery Burn Cave; 8-11) Flag Fen (images taken from Britton 1968: GB.55 10 (10); Lawson 1979: 175; Needham \& Hook 1988: 261; Coombs 2001: 273; Needham et al. 2013: 89; Mepham \& Schuster 2014: 180; Ahmet 2017; courtesy of Wessex Archaeology; scale 1:2).

Parallels for the Cliffs End Farm lead weight can be found in examples from Central Europe (Pare 1999; Feth 2014), dating to the later eleventh to ninth centuries BC. The lead weight from Cliffs End Farm was recovered from a pit containing five burials, one of which has been identified by strontium and oxygen isotope analyses as an adult of possible 'Scandinavian' origin, while a juvenile individual could have been of 'Mediterranean' origin (Millard 2014: 136-44). Seven of the 13 Late Bronze Age individuals subjected to isotope analyses from the site showed evidence for migration. Elsewhere, the Salcombe site, located off the coast of Devon, has yielded a bronze cast weight with wavy mouldings (Figure 2.2; Needham et al. 2013: 89, fig. 3.22; Needham 2017: fig. 4.4). Investigation of this site has also produced nearly 400 metal objects, comprising mainly copper and tin ingots (Wang et al. 2016, 2018), along with weapons and gold objects, including several gold bar torc fragments. Several ships have been wrecked at this location (most recently in 1992), and there is a "high probability that two temporally distinct Bronze Age shipwrecks can be identified at Salcombe" (Wang et al. 2016: 90). One wreck can be attributed to the Middle Bronze Age (c. 1300-1150 BC), the other to the Late Bronze Age (c. 1000-800 BC).

A further copper-alloy weight featuring three equally spaced wavy lines was found in the parish of Denton with Wootton, near Dover, in 2017 (Figure 2.3; Ahmet 2017). The two weights from Salcombe and Denton with Wootton morphologically resemble those usually (C) Antiquity Publications Ltd, 2019 
found in late fourteenth- and thirteenth-century BC western Central European graves (Figure 3), such as the weight from the securely dated burial at Richemont-Pépinville in France, as described by Pare (1999) and most recently also by Needham (2017:37). Notably, at least seven other similar weights (although cast in lead) are published in the Portable Antiquities Scheme database. The choice of lead as the material for these objects, along with their iron wire inlays, indicates a later date, suggested to be either Roman (Simpson 2006) or medieval/post-medieval (e.g. Stewart 2014). Even if these objects are probably not of Late Bronze Age or even Iron Age date, the furrows and inlays still imitate the thirteenth-century BC tradition of bronze-alloy weights of this type. It is hoped that a stratified, securely dated example will address this problem in the near future.

Another type of weight from the Late Bronze and possibly Early Iron Age are block-weights that lack decoration. There is a copper-alloy block-weight from Salcombe (Figure 2.4; Needham et al. 2013: 89, fig. 3.21). Such block-weights are again found in Central Europe in late fourteenth- and thirteenth-century BC contexts, such as at Horušany in Bohemia or Hurlach in Bavaria (Pare 1999: figs $10.2 \& 12.2$ ). Given the date of the bronze weight with wavy mouldings from Salcombe, a thirteenth-century BC date for the block-weight from the same site seems probable. This copper-alloy block-weight resembles other potential weights made of lead discovered at Runnymede Bridge in southern Britain (Figure 2.5) and in the

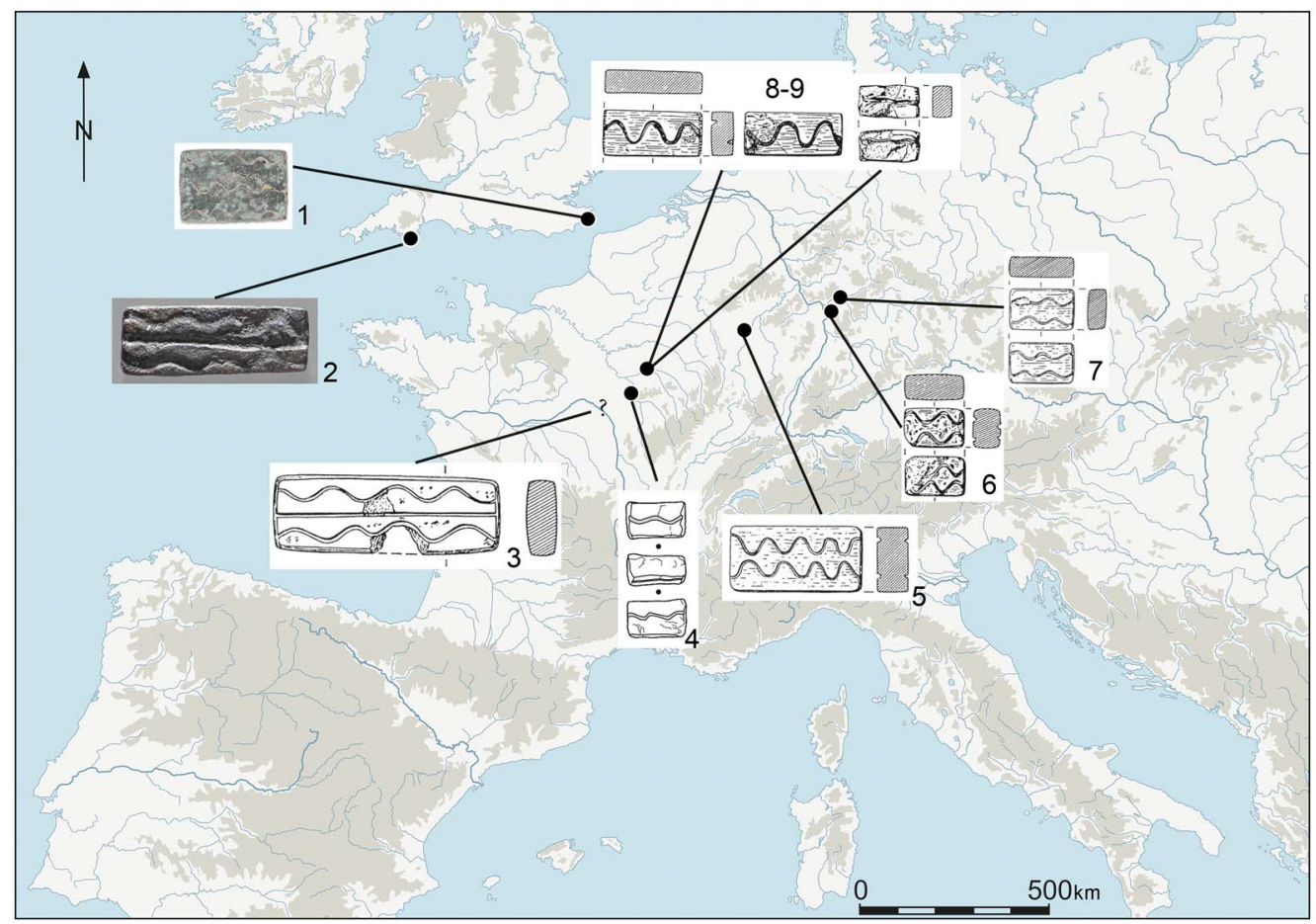

Figure 3. Distribution map of bronze rectangular block-weights with wavy mouldings from Britain (1-2), France (35, 8-9) and Germany (6-7): 1) Denton with Wootton; 2) Salcombe; 3) 'Sologne'; 4) Etigny; 5) Richemont-Pépinville; 6) Wallerstädten; 7) Maintal-Wachenbuchen; 8-9) Barbuise-Courtavant (images taken from Pare 1999: 447; Delor et al. 2009: 27; Needham et al. 2013: 89; Ahmet 2017; scale 1:2). 
hoard from West Caister, Norfolk (Figure 2.6; Lawson 1979: fig. 9.2; Needham \& Hook 1988: fig. 2.1). Both Runnymede Bridge and Potterne (where the bone balance (Figure 1.1) was discovered) are midden sites with substantial deposits of organic material and artefacts, but little other evidence of habitation. While they are generally considered to be communal feasting sites (Madgwick \& Mulville 2015: 641), the presence of weighing equipment suggests that exchange was also commonly practised at these sites. Hence, these Late Bronze Age and Early Iron Age middens could perhaps be interpreted as regional communal feasting sites with marketplace functions (Lawson 2000: 270; Rahmstorf 2018: 32-34).

The Flag Fen site has yielded one block-weight and three discoidal lead weights (Figure 2.8-11), although no details on their weights are provided (Coombs 2001: 291). Similar block- and discoidal weights are known from Central Europe and are consistently dated to the thirteenth century BC (e.g. Pare 1999: figs. 10.2, 12.1, 19.11)—although these are made of copper alloy. The lead weights from Britain, however, date to the latest phase of the Bronze Age (c. tenth to ninth centuries BC) and earliest Iron Age (eighth to seventh centuries BC). Finally, a stone object from the Late Bronze Age hoard discovered at Heathery Burn Cave in County Durham is probably a weight, given its shape and finish (Figure 2.7). In summary, 11 Middle Bronze to Early Iron Age objects, which cluster mainly in southern Britain, are presented here as potential weights using comparative evidence (see Table $S 1$ in the online supplementary material (OSM)). These data, however, are insufficient for metrological and statistical analyses. Nevertheless, the presence of the two bronze weights with wavy furrows imply that weight metrology was already in use in southern Britain by the thirteenth century BC.

\section{Middle and Late Bronze Age weight-regulated gold artefacts}

Flanged twisted gold bar torcs (Figure 4.1-6) are a feature of later second-millennium BC Britain, Atlantic France and Iberia, being used predominantly between 1300 and 1150 BC. While most of these gold bar torcs are single, stray finds, in 25 per cent of cases (e.g. Figure 4.1), they were found in association with other objects. The torcs are often found in coastal regions, or even offshore-indicating potential shipwrecks. In addition to the possible wreck site at Salcombe (Figure 4.2), torcs have been found up to $5.5 \mathrm{~km}$ from the coasts at Sotteville-sur-Mer and in the Minch, just off the Shiant Islands in the Outer Hebrides (Cowie 1994; Billard et al. 2005). The detailed typological classifications of these artefacts (e.g. Eogan 1967; Northover 1989: 118) notwithstanding, they are all characterised by pronounced club-shaped ends and the use of twisted thick gold wire in between.

Several authors have pointed out the clustered distribution of the weights of these torcs (Hawkes 1932: 180; Northover 1989: 125-26; Meeks \& Varndell 1994: 2). Ruiz-Gálvez (2000: tab. 18.4) went further and proposed a specific 'unit' of $11.75 \mathrm{~g}$. No previous author, however, has applied statistical tests to the weights of these gold torcs. Here, therefore, the weight of each complete specimen of the flanged twisted gold bar torcs is evaluated using cosine quantogram analysis (Table S2). Data on most of the torc weights are taken from Northover (1989: tab. 4) and Eogan (1967, 1994: 127-30). In cases where differing values are published for the same object, the most recent measurement is used. Uncleaned specimens (Varndell et al. 2007: 281) are not included in the sample. The sample clusters between approximately

(C) Antiquity Publications Ltd, 2019 


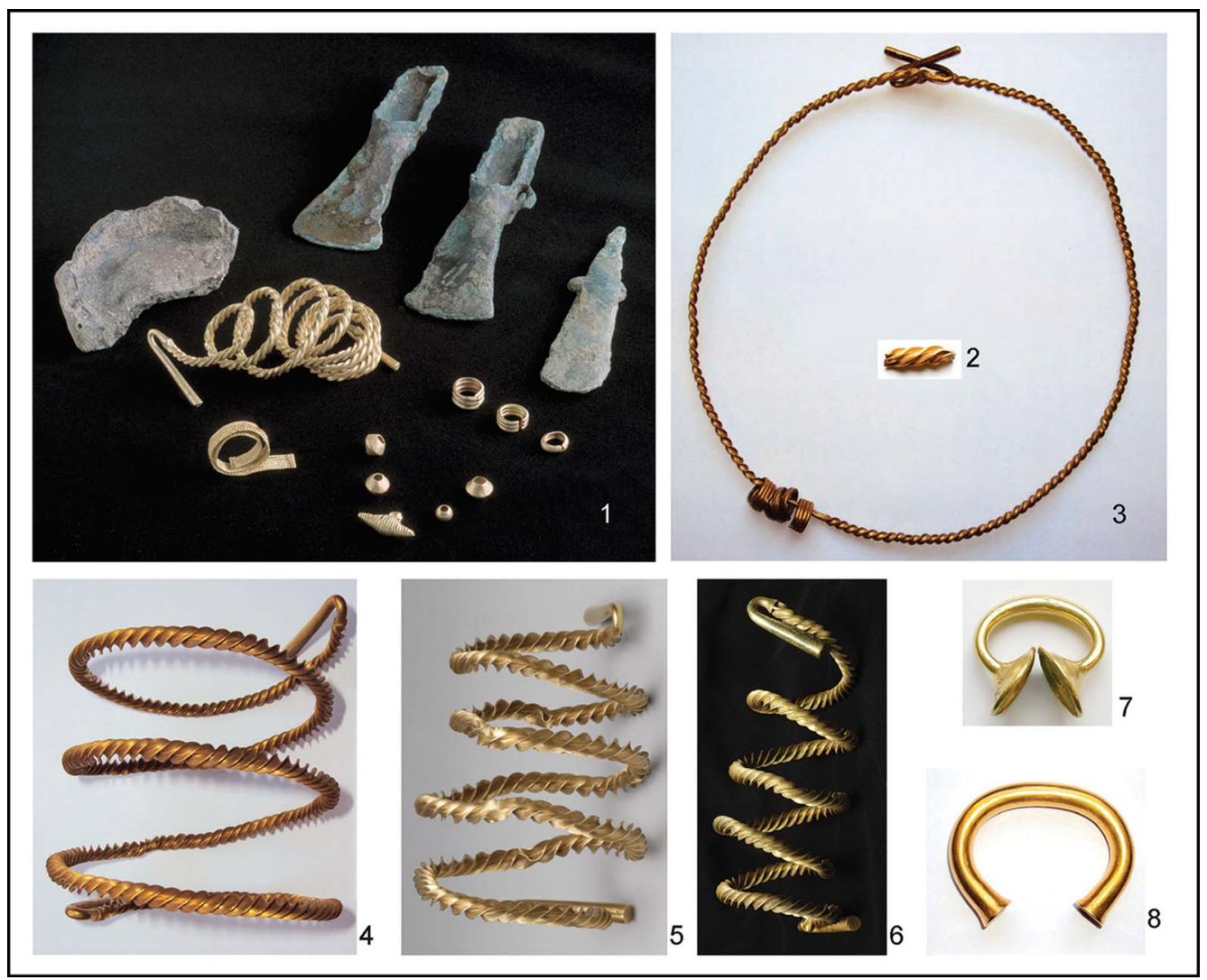

Figure 4. Gold objects from Middle and Late Bronze Age Britain and Ireland: 1) Burton (92.90g); 2) Salcombe (9.20g); 3) Axholme (94.22g); 4) Glamorgan (231.46g); 5) Castlemount (367.09g); 6) Corrard (720g); 7) unknown (124.60g); 8) Monkston Park, Milton Keynes hoard (382.4g) (images taken from Barton 2011; courtesy of the British Museum and the Ulster Museum; scale 1:4; 1 \& 5-6 are without scale).

80 and $400 \mathrm{~g}(\mathrm{n}=52)$. Five objects range between approximately 30 and $70 \mathrm{~g}$, representing outliers in the distribution. As the inclusion of outliers could skew the results, leading to false positives/negatives (Ialongo 2018), these objects were omitted from the analysis.

The cosine quantogram analysis was set to assess 1000 quanta between 4 and 103.9, with an increment of 0.1 . This results in high positive peaks at 11.6-11.9, 15.1-15.7, 22.6-24.5, 43-47 and 90-97. All seem internally coherent, with approximately 93.5 as a unit of 1 , hence 46 as $1 / 2,15.3$ as $1 / 6,23.4$ as $1 / 4$ and 11.7 as $1 / 8$. The results were tested for statistical significance using Monte Carlo simulations, under the null hypothesis that the distribution of weight values is due to chance (Ialongo 2018): a random fraction of \pm 15 per cent is added to each measurement and the simulation applied 100 times, with each resulting dataset examined using cosine quantogram analysis. If randomised samples consistently score higher values than the real sample, then chance distribution of the sample cannot be excluded. The alpha level is set to 0.05 ; hence, equal or higher results must not occur in more than five per cent of the iterations in order for the null hypothesis to be rejected. The dashed line in Figure 5A indicates the five per cent alpha level-the least acceptable statistically

(C) Antiquity Publications Ltd, 2019 
relevant threshold of consistency. Two peaks, 11.6-11.9 and 90-97, score higher than the five per cent line, suggesting statistical significance. The result is, however, only barely significant. Perhaps each object was not, therefore, meant to be regulated by weight, or the regulation was only approximate. This would be unsurprising, as the objects themselves are not balance weights. Perhaps approximately $11.6-11.9 \mathrm{~g}$ or $90-97 \mathrm{~g}$ were the ancient weight units-although these values could also represent a fraction, or a multiple of one or more units. This is illustrated by the Towednack hoard (Hawkes 1932: 190) from Cornwall, which not only comprised two gold bar torcs but also seven bracelets or ingots (28.4g; $29.1 \mathrm{~g} ; 30.5 \mathrm{~g}-47.8 \mathrm{~g}-62.5 \mathrm{~g} ; 63 \mathrm{~g}-94.6 \mathrm{~g} ; 95.5 \mathrm{~g} ; 96.5 \mathrm{~g}$ ). These can be interpreted as a logical series of fractions (1/3-1/2-2/3-1) of approximately $93 \mathrm{~g}$, but also, for example, of 46.5 (2/ $3-1-4 / 3-2$ ). Similarly, the Moulsford gold bar torc consists of four twisted bars bound by a thin gold wire and sheet-gold socketed terminal. The torc weighs a total of $373 \mathrm{~g}$ or $4 \times$ 93.25g.

In addition, a number of other gold artefacts from the British Isles are also tested here for any quantal organisation. These are the 'dress fasteners' (Figure 4.7) and penannular bracelets (Figure 4.8), as defined by Eogan (1994). Both categories are difficult to differentiate typologically and they appear together in hoards (e.g. Eogan 1983: 165, fig. 56B). While they date predominantly to the Late Bronze Age, they are also known from the Middle Bronze Age. In order for the analysis to be comparable to that of gold bar torcs, only artefacts above approximately $75 \mathrm{~g}$ are used for the cosine quantogram analysis $(\mathrm{n}=100)$. The plotted graph has peaks at 41-46 and 90-97, but also at 75-83 (Figure 5B); the latter seems to be a false positive. When all the data for the bar torcs, dress fasteners and the penannular bracelets are analysed collectively with cosine quantogram analysis $(n=152)$, statistically relevant peaks are obtained at approximately 41-46 and 90-97 (Figure 5C), which are higher than the results for the gold bar torcs analysed alone. The statistical tests reject the null hypothesis, and we can conclude that the analysed gold finds were probably structured according to one quantum, or several quanta: they were produced with a carefully measured amount of gold. The weight unit cannot be determined, but approximately $90-97 \mathrm{~g}$, or fractions or multiples of these ranges, are possible. Finally, while most gold ornaments appear to have been deposited intact (Roberts 2007: 148), the gold bar torcs are frequently found as intentionally cut fragments (Figure 4.2)—a phenomenon attested by the many fragments recorded in the Portable Antiquities Scheme database. Moreover, the presence of penannular bracelet fragments (Gwilt et al. 2005; Warner \& Cahill 2012) support the idea of a correlation between these artefacts and the gold bar torcs.

\section{Discussion}

Due to the limited number of known potential weights and the difficulties of securely dating many of them, it would be unwise to include them as evidence for the existence of particular weight units. The potential unit of approximately $93 \mathrm{~g}$ of the gold objects, however, is notable, as it is also known from other contexts: a unit of approximately 90-95g is attested across the contemporaneous Bronze Age and Early Iron Age Eastern Mediterranean. Egyptian written sources record the use of a $d b n$ (deben) and a related unit of $1 / 10$ called a qdt (qedet) (Pommerening 2012: 7089). Both measures—but especially the deben—are evident in the 149 weights recovered from the late fourteenth-century BC Uluburun shipwreck near

(C) Antiquity Publications Ltd, 2019 


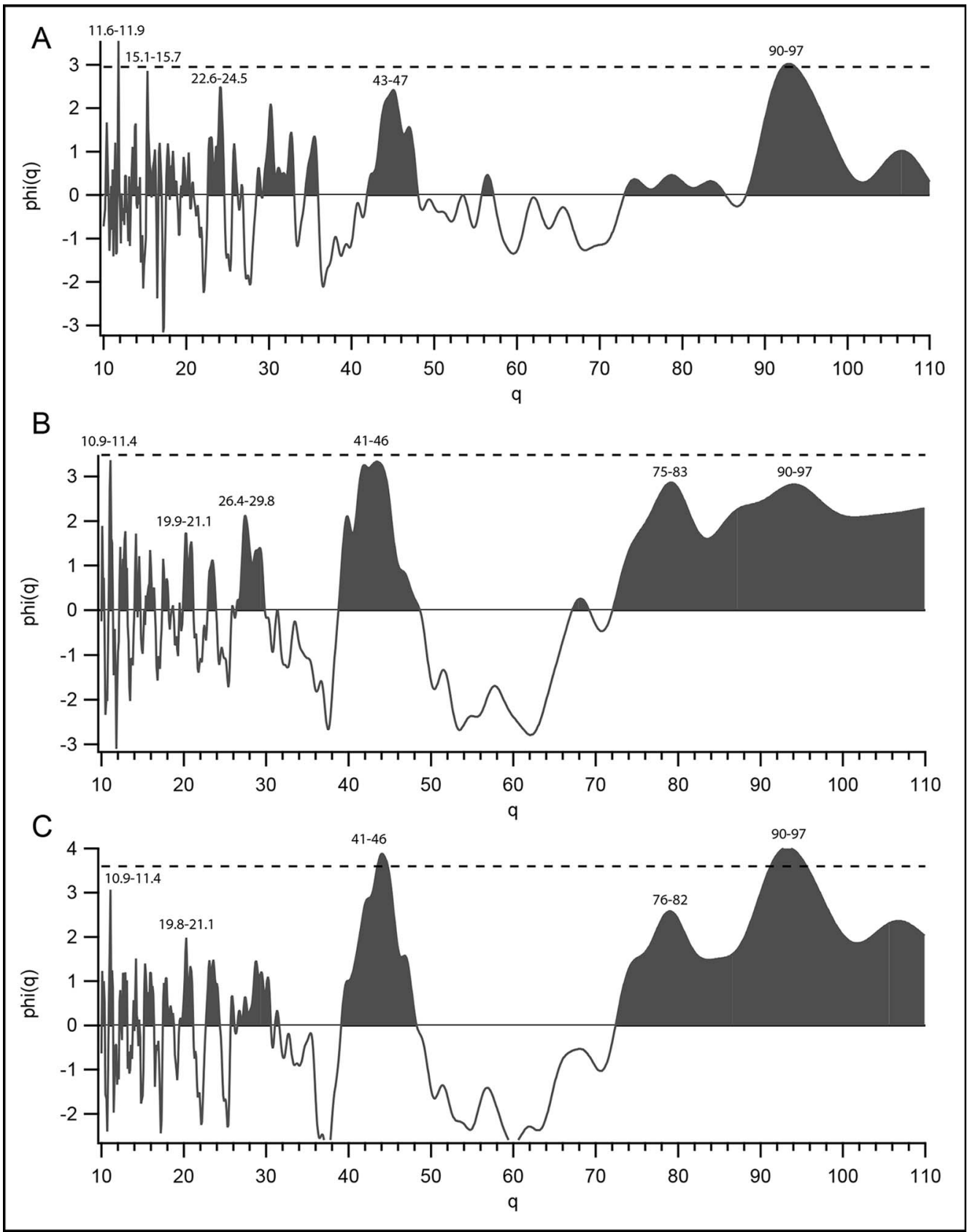

Figure 5. A) Cosine quantogram analysis of all completely preserved gold bar torcs with a known mass above $70 \mathrm{~g}(\mathrm{n}=$ 52); B) cosine quantogram analysis of penannular gold bracelets and gold 'dress fasteners' with a known mass above $70 \mathrm{~g}$ $(n=100) ; C)$ cosine quantogram analysis of all completely preserved gold bar torcs, penannular gold bracelets and gold 'dress fasteners' with a known mass above $70 \mathrm{~g}(n=152)$. 
Kas on the southern Anatolian coast, 13 of which range in mass from 90.3-94.65g (Pulak 2000: 252-53). Further weights from this assemblage measure twice, three, five, 10, 20 and 80 times this value of the deben (Pulak 2000: 253). Vilaça (2011) suggests that the qedet is attested in the contemporaneous Western Mediterranean by light metal weights from Portuguese Late Bronze to Early Iron Age sites. This unit was apparently also used for ninth-century BC lead cubes, found at Huelva in southern Spain (Gonzáles de Canales et al. 2006: fig. 36). We do not know whether the British and Mediterranean weight systems were connected. The analyses, however, suggest that they were perfectly compatible and that they could have been easily converted from one to the other.

There are a few archaeological finds that suggest some exchange between southern Britain and the Mediterranean as early as the thirteenth century BC. Along with the weights, the site of Salcombe has also yielded a Sicilian strumento con immanicatura a cannone-perhaps a plough shoe (Needham \& Giardino 2008; Needham et al. 2013: 85-86). Such a device has hitherto only been found in thirteenth- to eighth-century BC contexts in Sicily (Giardino 1995: 17-26, 291-92). Furthermore, Pantalica-type razors have been found at Lakenheath, Suffolk, and in a hoard at Ommerschans in the Netherlands (Jockenhövel 1980: 80-81). Again, such razors are otherwise known only from Sicily. The earliest meat hooks from southern British Middle Bronze Age sites, such as the examples from the Feltwell hoard, Flag Fen, Eriswell and Langdon Bay (another potential shipwreck), are also best paralleled with finds from thirteen-century BC Sicilian hoards (Needham \& Bowman 2005).

The Late Bronze Age balance beams from Potterne (Figure 1.1) and several French sites (Peake et al. 1999: fig. 1.2-3), such as Migennes in Bourgogne (Roscio et al. 2011: fig. 6.1), exhibit trumpet-shaped ends. This feature has an origin in the parasol-like umbel of a papyrus stem found on balance beams in Middle and Late Kingdom Egypt and the Late Bronze Age Eastern Mediterranean (Michailidou 2008: fig. III: 22-25). In addition, the trumpet-shaped ends of the balance beams are mimicked by two straight gold bars, an "unprovenanced unfinished bracelet blank" and an "unfinished cup-ended ornament blank" from Inchigeelagh, County Cork, Ireland (Taylor 1980: fig. 54a-b). Further to two scales, grave 298 from Migennes contained small metal weights and also one roughly ovoid stone object with slightly flattened ends (Rahmstorf 2014: fig. 3.13), the latter resembling Eastern Mediterranean sphendonoid weights, such as those from Uluburun. All of these connections, however, are imprecise in nature and limited in number. On present evidence, caution should still be exercised when explaining the weight unit of weight-regulated gold artefacts as being based on, or directly related to, the Eastern Mediterranean weight unit, which must then have disseminated from the Mediterranean to Atlantic France and the British Isles. The rectangular weights with wavy lines may indicate, on the contrary, a Central European contribution to the emergence of metrology in the British Isles.

The phenomenon of weight-regulated objects made from precious metals is not limited to thirteenth- and twelfth-century BC Western Europe: gold and silver rings with knobbed ends are found as complete and fragmented examples at a few third-millennium BC Aegean sites (e.g. Troy; Tolstikow \& Trejster 1996: nos 75-77, 163). Preliminary analysis of a few of these suggests potential weight regulation of the complete and fragmented examples (Rahmstorf 2016: 32-33). Silver rings from the Viking Age-the so-called Permian rings—were also made according to defined weight groups. Again, these have spiral grooves and are wound (C) Antiquity Publications Ltd, 2019 
two or three times. In addition, they have pronounced ends, generally comprising a single facetted knob on one end and a hook on the other (Hårdh 2016). It was apparently important to mark the ends of such objects: it would be clearly visible if something was later removed from the object, thus its use in weight-regulation could be ended. Winding may be an additional feature indicating that the mass of the object was measured when it was produced. The similarity in features - that is, being twisted into a spiral and having pronounced ends, torsion, clipped fragments and weight-regulation - indicate that similar solutions were used during different periods for creating a bullion-currency used in production and exchange.

\section{Conclusions}

The evidence presented here strongly suggests that the practice of systematically measuring value was known in Middle and Late Bronze Age Britain. Although the number of weights securely dated to this period is still very low, and so far limited largely to southern Britain, it is reasonable to assume that more weights — perhaps also made of stone and of irregular shapes - may have passed unnoticed. The use of scales and of specific gold artefacts, such as bar torcs, penannular bracelets and dress fasteners from the British Isles and Atlantic France, as apparent weight-regulated artefacts strengthens the assumption of exchange structured by value ratios, based on weight units. Often intentionally cut, the gold artefacts seem to have been used as a 'hackgold' - currency in exchange transactions. The weights known so far are rather light — an additional indication that gold was one of the potential reference materials for the value ratios, as well as a key commodity in the trade within the British Isles and beyond. The compliance of weight-regulated gold artefacts from the British Isles to an Eastern Mediterranean weight standard remains difficult to explain, but the convergence may at least emphasise long-range connectivity during the Bronze Age.

\section{Acknowledgements}

This work was supported by ERC-2014-CoG 'Weight and Value: Weight Metrology and its Economic and Social Impact on Bronze Age Europe, West and South Asia' (grant 648055). I would like to thank the following for providing me with information and unpublished data, and for granting me access to finds or to permits of reproduction: Pippa Bradley, Catherine Louboutin, Stuart Needham, Jan Schuster, Alison Sheridan, Gillian Varndell, Neil Wilkin and Jim Wilson. Many thanks are due to Eleonore Pape and especially to Ben Roberts and Nicola Ialongo for discussions and many suggestions for improvement. I would like to thank the Trustees of the British Museum, Wessex Archaeology and the Portable Antiquities Scheme for permission to reproduce illustrations.

\section{Supplementary material}

To view supplementary material for this article, please visit https:/doi.org/10.15184/aqy. 2018.257.

\section{References}

Ahmet, J. 2017. ID: KENT-115078: an unknown weight. Available at:

https://finds.org.uk/database/artefacts/record/id/ 854238 (accessed 31 May 2019).
Barton, C. 2011. ID: PAS-5B1745: a Bronze Age hoard. Available at:

https://finds.org.uk/database/artefacts/record/id/ 436588 (accessed 31 May 2019).

Billard, C., C. Eluere \& M.-P. Jezegou. 2005.

Découverte de torques en or de l'âge du Bronze en 
mer de Manche, in J. Bourgeois \& M. Talon (ed.) L'áge du Bronze du nord de la France (Actes des congrès nationaux des sociétés historiques et scientifiques $125^{\mathrm{e}}$ ): 287-301. Paris: CTHS.

Britton, D. 1968. Inventaria archaeologica. Great Britain $9^{\text {th }}$ set: GB.55. London: British Museum.

BRÜCK, J. 2006. Death, exchange and reproduction in the British Bronze Age. European Journal of Archaeology 9: 73-101. https://doi.org/10.1177/1461957107077707

Cardarelli, A., M. Pacciarelli \& P. Pallante. 1997. Pesi e bilance dell'età del Bronzo?, in M. Bernabò-Brea, A. Cardarelli \& M. Cremaschi (ed.) Le Terramare, la più antica civiltà padana: 629-42. Milano: Electra.

Coombs, D. 2001. Metalwork, in F. Pryor (ed.) The Flag Fen basin: archaeology and environment of a Fenland landscape: 255-97. Swindon: English Heritage.

Cowie, T. 1994. A Bronze Age gold torc from the Minch. Hebridean Naturalist 12: 19-21.

Delor, J.-P., F. Muller \& M. Roscio. 2009. L'exceptionnelle sépulture d'un orfevre de l'Âge du Bronze à Migennes. L'Écho de Joigny 69: 7-30.

Eogan, G. 1967. The associated finds of gold bar torcs. The Journal of the Royal Society of Antiquaries of Ireland 97: 129-75.

- 1983. The hoards of the Irish later Bronze Age. Dublin: University College.

- 1994. The accomplished art: gold and gold-working in Britain and Ireland during the Bronze Age (c. 2300-650 BC). Oxford: Oxbow.

Feth, W. 2014. HaB-zeitliche Waaggewichte?, in B. Nessel, I. Heske \& D. Brandherm (ed.) Ressourcen und Rohstoffe in der Bronzezeit: Nutzung-Distribution-Kontrolle (Arbeitsberichte zur Bodendenkmalpflege in Brandenburg 26): 109-20. Wünsdorf: Brandenburgisches Landesamt für Denkmalpflege und Archäologisches Landesmuseum.

Giardino, G. 1995. Il Mediterraneo occidentale fra XIV ed VIII secolo a. C. Cerchi minerarie e metallurgiche (British Archaeological Report International series 612). Oxford: Tempus Reparatum.

Gonzales De Canales, F., L. Serrano \& J. Llompart. 2006. The pre-colonial Phoenician emporium of Huelva c. 900-700 BC. Babesch, Bulletin Antieke Beschaving 81: 13-29.
Grimm, J.M. \& J. Schuster. 2014. Worked bone, in J.I. McKinley, M. Leivers, J. Schuster, P. Marshall, A.J. Barclay \& N. Stoodley (ed.) Cliffs End Farm, Isle of Thanet, Kent (Wessex Archaeology Report 31): 187-92. Salisbury: Wessex Archaeology.

Gwilt, A., K. Kucharski, R. Silvester \& M. Davis. 2005. A Late Bronze Age hoard from Trevalyn Farm, Rossett, Wrexham. Studia Celtica 34: 27-61.

HÅRDH, B. 2016. The Perm'/Glazov rings. Contacts and economy in the Viking Age between Russia and the Baltic region (Acta Archaeologica Lundensia 8 (67)). Lund: Lund University.

Harding, A. 2013. Trade and exchange, in H. Fokkens \& A. Harding (ed.) The Oxford handbook of the European Bronze Age: 370-81. Oxford: Oxford University Press.

Hawkes, C. 1932. The Towednack gold hoard. Royal Anthropological Institute of Great Britain and Ireland 32: 177-86.

IALONGO, N. 2018. The earliest balance weights in the west: towards an independent metrology for Bronze Age Europe. Cambridge Archaeological Journal 29: 103-24. https://doi.org/10.1017/S0959774318000392

Ialongo, N. \& L. Rahmstorf. In press. The identification of balance weights in pre-literate Bronze Age Europe: typology, chronology, distribution and metrology, in L. Rahmstorf \& E. Stratford (ed.) Weights and marketplaces from the Bronze Age to the early modern period (Weight and Value 1). Kiel \& Hamburg: Wachholtz.

Ialongo, N., A. VacCa \& L. Peyronel. 2018. Breaking down the bullion. The compliance of bullion-currencies with official weight-systems in a case-study from the ancient Near East. Journal of Archaeological Science 91: 20-32. https://doi.org/10.1016/j.jas.2018.01.002

Jockenhövel, A. 1980. Die Rasiermesser in Westeuropa (Prähistorische Bronzefunde VIII, 3). München: C.H. Beck'sche.

Lawson, A.J. 1979. A Late Bronze Age hoard from West Caister, Norfolk, in C. Burgess \& D. Coombs (ed.) Bronze Age hoards: some finds old and new (British Archaeological Reports British series 67): 173-79. Oxford: British Archaeological Reports Publishing.

- 2000. Potterne 1982-5: animal husbandry in later prehistoric Wiltshire (Wessex Archaeology Report 17). Salisbury: Wessex Archaeology. 


\section{Scales, weights and weight-regulated artefacts in Middle and Late Bronze Age Britain}

Madgwick, R. \& J. Mulville. 2015. Feasting on fore-limbs: conspicuous consumption and identity in later prehistoric Britain. Antiquity 89: 629-44. https://doi.org/10.15184/aqy.2015.24

Meeks, N.D. \& G.L. Varndell. 1994. Three Bronze Age torc fragments from Woodham Walter, Essex. Essex Archaeology and History 25: 1-2.

Mepham, L. \& J. Schuster. 2014. Bronze Age metalwork, in J.I. McKinley, M. Leivers, J. Schuster, P. Marshall, A.J. Barclay \& N. Stoodley (ed.) Cliffs End Farm, Isle of Thanet, Kent (Wessex Archaeology Report 31): 179-82. Salisbury: Wessex Archaeology.

Michailidou, A. 2008. Weight and value in pre-coinage societies, volume II. Paris: de Boccard.

Millard, A. 2014. Isotopic investigation of residential mobility and diet, in J.I. McKinley, M. Leivers, J. Schuster, P. Marshall, A.J. Barclay \& N. Stoodley (ed.) Cliffs End Farm, Isle of Thanet, Kent (Wessex Archaeology Report 31): 133-44. Salisbury: Wessex Archaeology.

Needham, S. 2017. Transmanche in the Penard/ Rosnoën stage. Wearing the same sleeve or keeping at arm's length?, in A. Lehoërff \& M. Talon (ed.) Movement, exchange and identity in Europe in the $2^{\text {nd }}$ and $1^{\text {st }}$ millennia BC: beyond frontiers: 31-48. Oxford: Oxbow.

Needham, S. \& S. Bowman. 2005. Flesh-hooks, technological complexity and the Atlantic Bronze Age feasting complex. European Journal of Archaeology 8: 93-136. https://doi.org/10.1177/1461957105066936

Needham, S. \& C. Giardino. 2008. From Sicily to Salcombe: a Mediterranean Bronze Age object from British coastal waters. Antiquity 82: 60-72. https://doi.org/10.1017/S0003598X00096447

NeedHam, S. \& D.R. Ноок. 1988. Lead and lead alloys in the Bronze Age-recent finds from Runnymede Bridge, in E.A. Slater \& J.O. Tate (ed.) Science and archaeology Glasgow 1987 (British Archaeological Reports British series 196): 259-74. Oxford: British Archaeological Reports Publishing.

Needham, S., D. Parham \& C.J. Frieman. 2013. Claimed by the sea: Salcombe, Langdon Bay, and other marine finds of the Bronze Age (CBA Research Report 173). York: Council for British Archaeology.

Northover, J.P. 1989. The gold torc from Saint Helier, Jersey. Annual Bulletin of the Societé Jersiaise 25: 112-37.
Pakkanen, J. 2011. Aegean Bronze Age weights, chainnes opératoires and the detecting of patterns through statistical analyses, in A. Brysbaert (ed.) Tracing social networks through studying technologies: a diachronical perspective from the Aegean: 143-66. London \& New York: Routledge.

PARE, C.F.E. 1999. Weights and weighing in Bronze Age Central Europe, in Eliten in der Bronzezeit. Ergebnisse zweier Kolloquien in Mainz und Athen, Teil 2 (Römisch-Germanisches Zentralmuseum, Monographien 43(2)): 421-514. Mainz: Römisch-Germanisches Zentralmuseum.

Peake, R., J.M Séguier \& J. Gomez De Soto. 1999. Trois exemplaires de fléaux de balance en os de l'Age du bronze. Bulletin de la Société préhistorique Française 96: 643-44. https://doi.org/10.3406/bspf.1999.11220

Pommerening, T. 2012. Weights and measures, Pharaonic Egypt, in R. Bagnall, K. Brodersen, C.B. Champion, A. Erskine \& R. Hübner (ed.) Encyclopedia of ancient history: 7087-92. Malden: Wiley-Blackwell.

https://doi.org/10.1002/9781444338386. wbeah 15415

PulaK, C. 2000. The balance weights from the Late Bronze Age shipwreck at Uluburun, in C.F.E. Pare (ed.) Metals make the world go round: 247-66. Oxford: Oxbow.

RahmSTORF, L. 2003. The identification of Early Helladic weights and their wider implications, in K. Foster \& R. Laffineur (ed.) Metron. Measuring the Aegean Bronze Age. Proceedings of the $9^{\text {th }}$ International Aegean Conference, New Haven, Yale University 18-21 April 2002 (Aegaeum 24): 293-8. Liège: Université de Liège.

- 2014. 'Pebble weights' aus Mitteleuropa und Waagebalken aus der jüngeren Bronzezeit (c. 14.12. Jh. v. Chr.), in B. Nessel, I. Heske \& D. Brandherm (ed.) Ressourcen und Rohstoffe in der Bronzezeit: Nutzung —DistributionKontrolle (Arbeitsberichte zur Bodendenkmalpflege in Brandenburg 26): 10920. Wünsdorf: Brandenburgisches Landesamt für Denkmalpflege und Archäologisches Landesmuseum.

- 2016. From 'value ascription' to coinage: a sketch of monetary developments in Western Eurasia from the Stone to the Iron Age, in S. Krmnicek \& C. Haselgrove (ed.) The archaeology of money 
(Leicester Archaeological Monograph 24): 19-42. Oxford: Oxbow.

- 2018. Of middens and markets: the phenomenology of the market place in the Bronze Age and beyond, in J. Hahn \& G. Schmitz (ed.) Market as place and spaces of economic exchange. Archaeological and anthropological perspectives: 20-40. Oxford: Oxbow.

RoBerTs, B.W. 2007. Adorning the living but not the dead: understanding ornaments in Britain $c$. 1400-1100 cal BC. Proceedings of the Prehistoric Society 73: 135-66. https://doi.org/10.1017/S0079497X00027328

Roscio, M., J.-P. Delor \& F. Muller. 2011. Late Bronze Age graves with weighing equipment from eastern France. Archäologisches Korrespondenzblatt 41: 173-87.

Ruiz-GÁlvez, M. 2000. Weight systems and exchange networks in Bronze Age Europe, in C.F.E. Pare (ed.) Metals make the world go round: 267-79. Oxford: Oxbow.

Seager Smith, R. 2000. Worked bone and antler, in A.J. Lawson (ed.) Potterne 1982-5: animal husbandry in later prehistoric Wiltshire (Wessex Archaeology Report 17): 222-40. Salisbury: Wessex Archaeology.

Simpson, F. 2006. ID: LON-6A4983: a Roman weight. Available at: https://finds.org.uk/database/artefacts/record/id/ 126201 (accessed 31 May 2019).

StewART, G. 2014. ID: SF-021CF7: an unknown weight. Available at:

https://finds.org.uk/database/artefacts/record/id/ 622782 (accessed 31 May 2019).

TAYLOR, J.J. 1980. Bronze Age goldwork of the British Isles. Cambridge: Cambridge University Press.
Tolstikow, P. \& M.J. Trejster. 1996. The treasure from Troy. Stuttgart: Belser.

Varndell, G., D. Coe \& G. Hey. 2007. The Crow Down hoard, Lambourn, West Berkshire. Oxford Journal of Archaeology 26: 275-94. https://doi.org/10.1111/j.1468-0092.2007. 00285.x

VILAÇA, R. 2003. Acerca da existência de ponderais em contextos do Bronze Final/Ferro Inicial no território português. O Arqueólogo Português 21: 245-88.

- 2011. Ponderais do Bronze final-Ferro inicial do Ocidente peninsular: novos dados e questôes em aberto, in M.A. Paz García-Bellido, L. Callegarin \& A. Jiménez Díaz (ed.) Barter, money and coinage in the ancient Mediterranean $\left(10^{\text {th }}-1^{\text {st }}\right.$ centuries BC) (Anejos de Archivo Español de Arqueología 58): 139-68. Madrid: CSIC.

Wang, Q., S. Strekopytov, B.W. Roberts \& N. WILKIN. 2016. Tin ingots from a probable Bronze Age shipwreck off the coast of Salcombe, Devon: composition and microstructure. Journal of Archaeological Science 67: 80-92. https://doi.org/10.1016/j.jas.2016.01.018

WANG, Q., S. Strekopytov \& B.W. Roberts. 2018. Copper ingots from a probable Bronze Age shipwreck off the coast of Salcombe, Devon: composition and microstructure. Journal of Archaeological Science 97: 102-17. https://doi.org/10.1016/j.jas.2018.07.002

Warner, R. \& M. Cahill. 2012. The Downpatrick hoards: an analytical reconsideration, in J.R. Trigg (ed.) Of things gone but not forgotten. Essays in archaeology for Joan Taylor (British Archaeological Reports International series 2434): 95-108. Oxford: Archaeopress.

Received: 16 March 2018; Revised: 16 October 2018; Accepted: 15 November 2018

(C) Antiquity Publications Ltd, 2019 